\title{
An Invasive Ductal Carcinoma in Behcet's Disease
}

\section{Behçet Hastalığında İnvaziv Duktal Karsinom}

Yasemin Benderli Cihan

Kayseri Eğitim Ve Araştırma Hastanesi, Radyasyon Onkoloji, Kayseri, Türkiye

Doi: $10.5505 /$ aot.2012.02996

Anahtar Kelimeler: Meme kanseri; Behçet hastalığı; Radyoterapi

Key words: Breast cancer; Behcet disease; Radiotherapy

\section{Sayın Editör,}

Behçet hastalığına eşlik eden kanser olgularının bildirildiği çok az olgu vardır. Behçet hastalığında kullanılan kolşisin, prednizolon ve azotiopürinin kanser gelişimini indüklediği düşünülmektedir (1-3). Bu yazıda, Behçet seyri sırasında gelişen meme kanseri olgusu sunuldu.

Otuzdokuz yaşında bayan hasta 9 yıl önce Behçet Hastalığı tanısı konulmuş. Üç yıl önce kolşisin tedavisine rağmen hastalığın aktivasyonu nedeniyle azotiopürin kullanmaya başlamış. Memede kitle şikâyeti ile yapılan ince iğne aspirasyon biyopsi sonucunun malign gelmesi üzerine segmental mastektomi ve aksiller diseksiyon yapıldı. Kemoterapi endikasyonu konulmayan hastanın meme bölgesine 56 Gy radyoterapi verildi. Radyoterapiden sonra LHRH analogu ve Tamoksifen başlanılarak takibe alındı. Behçet hastalığ 1 için ise prednizolon tedavisi almaktadır. Onbeş aydır takip edilen hasta kontrollere düzenli gelmektedir. Hastada Behçet hastalığına bağlı sol gözde kısmi görme kaybı dışında herhangi bir şikayeti olmadı. Ayrıca hastada radyoterapiye bağlı akut ve geç morbidite gözlenmedi.
Behçet hastalığının seyrinde meme kanseri gelişimi için altta yatan nedenin otoimmün bozukluğun veya tedavide kullanılan ilaçların kanseri indüklediği düşünülmektedir $(1,2)$. Bu hastada, Behçet hastalığı ile meme kanserinin tesadüfen birlikte olduğu düşünüldü. Kollajen vasküler hastalıklarda artmış radyasyon toksisitesine dair birçok rapor olmasına rağmen Behçet hastalığ 1 için oldukça nadirdir (2). Bu olguda 15 aylık sürede akut ve geç radyasyon toksisitesi görülmedi.

Çıkar Çatışması: Yok

\section{Kaynaklar}

1. Kurtz JM, Almaric R, Delouche G, et al. The second ten years. Long-term risks of breast conservation in early breast cancer. Int J Radiat Oncol Biol Phys 1997; 13:327-32

2. Flect $\mathrm{R}$, McNeese $\mathrm{MD}$, Ellerblock NA, et al. Conseqences of breast irradiation in patients withprexisting collagen vascular diseases. Int J Radiat Oncol Biol Phys 1989;17:829-33

3. McCormick B: Radiation therapy for breast cancer. Curr Opinion Onc 1995;7:511-6 